\title{
Lessons Learned from COVID-19 Pandemic to Tackle Climate Change- Led Risks in Bangladesh
}

\author{
Md. Ayatullah Khan ${ }^{1 \star}$ \\ ${ }^{1}$ Development Studies Discipline, Khulna University, Khulna, BANGLADESH \\ *Corresponding Author: ayatullah.ku@gmail.com \\ Citation: Khan, M. A. (2022). Lessons Learned from COVID-19 Pandemic to Tackle Climate Change-Led Risks in Bangladesh. Agricultural and \\ Environmental Education, 1(1), em001. https://doi.org/10.29333/agrenvedu/11824

\begin{tabular}{|c|c|}
\hline ARTICLE INFO & ABSTRACT \\
\hline Received: 4 Nov. 2021 & The consequence of the COVID-19 outbreaks and continued crisis already gave us some crucial lessons as a \\
\hline Accepted: 16 Feb. 2022 & $\begin{array}{l}\text { baseline assessment to deal with in the context of climate change, which for the twenty-first century is a serious } \\
\text { challenge and risk to human survival. This report however describes the lessons learnt from the COVID-19 } \\
\text { pandemic and discusses them from Bangladesh viewpoint in tackling risks linked to the climate change. }\end{array}$ \\
\hline
\end{tabular}

Keywords: COVID-19, climate change, Bangladesh

\section{INTRODUCTION}

The novel coronavirus outbreak in 2019, also called COVID-19, is a world health crisis that has led to an unparalleled human life and livelihood disaster, disrupted economical processes across industries, stopped public transport networks, and limited global social interactions (Pathak et al., 2020). Bangladesh has announced their first three cases in Dhaka on 8th March, 2020 (Hasan \& Shaon, 2020). About 691,957 confirmed cases has been recorded comprising 9,822 deaths in Bangladesh as of 13th April, 2021 (Worldometer, 2021). In order to combat the spread of COVID-19, the government of Bangladesh has declared a nationwide lockdown. All the government and non-government institutions, as well as public transport, have been closed over the country apart from emergency services (Mamun, 2020; Noman, 2021). Thus, this pandemic situation is not constrained to health crises anymore, instead, it is becoming an unparalleled crippling effect on the social and economic contexts, and it appears with prolonged effects over time. Bangladesh has already experienced enormous economic and social instability as a result of the emerging COVID-19 pandemic. Middle-income, lower-income, and daily-wage earner households found themselves in a serious financial dilemma due to the loss of employment and wages during this situation. They are dropped into the extremely poor with their last savings consumed. Moreover, the decrease of export earnings and income from tourism due to the enforced border constraints and extended lockdowns has already been seen as the main contributors to a coming socioeconomic shock, as millions of populations of the country are engaged in these sectors (Banna, 2020; Shammi et al., 2020).

At the same time, climate change has an adverse impact on every country in the world. The impact of climate change has made developing countries much more vulnerable than the rest of the world. Migration, salinization, crop damage, water contamination, food security and livelihood loss, infrastructure damage, disasters frequency and intensity increase, poverty, health problems, and rapid urbanization are all exacerbated by climate change (Abedin et al., 2019; Alam \& Ahmed, 2010; Alamgir et al., 2020; Calzadilla et al., 2013). Bangladesh has already experienced the severity of these effects. The steady rising of sea levels and temperatures in combination with increasing regional climate change and extreme occurrences, such as extreme floods, droughts, and storms, are the major implications of climate change in Bangladesh (Khan et al., 2011). These issues have the foremost adverse effect on water infrastructure and supply systems, especially in coastal areas with saline water intrusion. Thus, the incidence of waterborne diseases has increased in these areas due to the contamination of water (Abedin et al., 2019). For instance, a recent diarrhea outbreak in the Barisal division has made headlines, leading to eight deaths and thousands of people being admitted to hospitals in six districts. According to healthcare professionals in the Barisal district, the cause of the problem is water pollution (Swapan \& Tuhin, 2021). Furthermore, due to a predicted $50 \mathrm{~cm}$ sea-level rise caused by climate change, Bangladesh will lose approximately $11 \%$ of its land by 2050 , impacting an estimated 15 million people living in its low-lying south-western coastal region, and approximately 18 million people may be forced to migrate (EJF, 2021). Additionally, climate change is considered as an interface dimension influencing agricultural production (key economic sector and a critical source of livelihood and employment) in various parts of the country. Agricultural production and livelihoods are being experienced progressively by the detrimental impacts from this acute stress. As a result, farming households are continued to have poor or negative net farm incomes. These are leading to poverty and inequality within the country (Alamgir et al., 2020). 
However, our daily life has been radically altered by the outbreak of COVID-19 and rendered us acutely aware of the ongoing vulnerability of society. The necessity for structural and institutional development line with the fundamentals of sustainability and resilience has conclusively demonstrated extreme importance (Hammer et al., 2021; Meuleman, 2021). The outbreak of this pandemic and continuing catastrophe has already instructed us some vital insights as a "stress test" that should be addressed when coping with climate change, which is a profound threat and danger to human existence for the twenty-first century and onward (Chasan, 2021). Thus, this paper outlines the learned lessons from the COVID-19 outbreak and relates them in the perspective of Bangladesh to tackle climate change-led risks. The paper allows us to better understand climate change concerns and trying to persuade relevant authorities of the country to develop policy initiatives to tackle this major global crisis.

\section{LESSON 1: PROBLEMS ON A GLOBAL SCALE REQUIRE (GLOBAL) COOPERATION}

COVID-19 is a global issue that cannot be prevented in check by geographical boundary lines, no matter how hard governments try. Regardless of how wealthy or impoverished the country is, it hits all countries on each continent. The lesson of this is that a country's economic success is a very ineffective determinant of how it can address the crisis effectively, as can be seen from the situation in COVID-19 in the wealthier region of the world at present (Huq, 2020; Klenert et al., 2020). As climate change is being increasingly to be a global issue, it requires an international collaboration to tackle the crisis. Bangladesh recently urged that the Paris Agreement be properly implemented. Furthermore, international collaboration in the fields of climate financing, mitigation, and adaptation to tackle the detrimental impacts of climate change on labor, human rights and health should be strengthened. The government tried to persuade the developed countries to provide appropriate financial, technological, and technical support to countries at risk of and impacted by climate change and global warming. However, the current intergovernmental and national climate collaboration of Bangladesh should be strengthened by the government.

\section{LESSON 2: MAKING APPROPRIATE FUNDING FOR MITIGATION AND PREPAREDNESS AS THE PRIORITY NOW}

Bangladesh has followed the path that most of the countries adopt, including progressive non-therapeutic measures to monitor nCoV-2 transmissions. There are, however, some complicated issues of the effective introduction and application of the measures. Several experts believe that $\mathrm{nCoV}-2$ may have entered the country earlier but was not detected due to inadequate surveillance, based on the confirmed date of the first case in the country (Perera, 2021). In addition, the number of confirmed cases and deaths started to rise overtime with the shortage of test kits, PPEs, institutional quarantine, and cooperation among implementation authorities. There have also been suspicions that serious inadequacy in testing could leave many cases in the country completely unnoticed (Anwar et al., 2020). While several countries, including South Korea, Hong Kong, Singapore, and Taiwan, have quickly approaching epidemic experiences in recent decades and slowing the spread of SARS-CoV-2 in its early stages (Klenert et al., 2020). Delays in implementing mitigation strategies during global crises are particularly devastating because quick response decreases expenses and casualties significantly. In the case of COVID-19, intervening quickly drawn a distinction between a protracted full-scale lockdown with a high number of fatalities and even less drastic interventions including expanded health surveillance at borders, contact tracking, public awareness promotions, and almost business-as-usual, as in Taiwan (Wang et al., 2020).

Policies on climate change must therefore be taken on even longer periods to compensate those delays are expensive indeed. A number of policy initiatives and institutional initiatives have been introduced by the Government of Bangladesh, including the National Adaptation Programmes of Action (NAPA) in 2005 and Bangladesh Climate Change Strategy and Action Plan in 2009, Perspective Plan to 2041, the Delta Plan to 2100, Mujib Climate Prosperity Plan 2020 (DhakaTribune, 2021; Huq, 2021). However, appropriate funding from the national treasury to implement and accomplish this agenda should be a major consideration. Moreover, the establishment of sustainable embankments in the coastal region should be effective immediately to reduce the damages and losses from climate change-induced disasters.

\section{LESSON 3: POLICIY GUIDANCE FROM EXPERTS IS REMARKABLY IMPORTANT}

There has been a considerable disparity in the proportion of deaths owing to coronavirus, in response by the respective authorities of nations, as well as in districts within nations and particular towns. Authorities who responded based on expert guidance and acted quickly, as well as offering logical and science-based guidance to their population and encouraging (instead of compelling) people to practice excellent hygiene, face masks, and social distancing, were able to maintain their corresponding death rates lower than others (Huq, 2020; Klenert et al., 2020). In the time of dealing with the effects of climate change in the near future, such learning will be beneficial. Moving ahead, national leaders and policy makers must pay attention to climate experts and start making their policies on optimally relevant information. 


\section{CONCLUSION}

While we are continuing with the COVID-19 trouble and the crisis of climate change is shaping up to worsen over time, it has already clear that early decisions based on best scientific evidence are going to save lives, livelihoods, agriculture, water, infrastructures, and environment of the country in the coming years.

Author notes: The author has agreed with the results and conclusions.

Funding: No funding source is reported for this study.

Declaration of interest: No conflict of interest is declared by the author.

\section{REFERENCES}

Abedin, M. A., Collins, A. E., Habiba, U., \& Shaw, R. (2019). Climate change, water scarcity, and health adaptation in Southwestern coastal Bangladesh. International Journal of Disaster Risk Science, 10, 28-42. https://doi.org/10.1007/s13753-018-0211-8

Alam, M. J. B., \& Ahmed, F. (2010). Modeling climate change: Perspective and applications in the context of Bangladesh. In Y. Charabi (Ed.), Indian ocean tropical cyclones and climate change (pp. 15-23). Springer. https://doi.org/10.1007/978-90-4813109-9_3

Alamgir, Md. S., Furuya, J., Kobayashi, S., Mostafiz, R. B., \& Ahmed, Md. R. (2020). Farm income, inequality, and poverty among farm families of a flood-prone area in Bangladesh: Climate change vulnerability assessment. GeoJournal, 86, $2861-2885$. https://doi.org/10.1007/s10708-020-10231-2

Anwar, S., Nasrullah, M., \& Hosen, M. J. (2020). COVID-19 and Bangladesh: Challenges and how to address them. Frontiers in Public Health, 8, 1-8. https://doi.org/10.3389/fpubh.2020.00154

Banna, H. (2020, March 15). Minimising the economic impact of Coronavirus in Bangladesh. The Business Standard. https://www.tbsnews.net/thoughts/minimising-economic-impact-coronavirus-bangladesh-56449

Calzadilla, A., Rehdanz, K., Betts, R., Falloon, P., Wiltshire, A., \& Tol, R. S. J. (2013). Climate change impacts on global agriculture. Climatic Change, 120(1-2), 357-374. https://doi.org/10.1007/s10584-013-0822-4

Chasan, E. (2021, May 3). Climate adaptation-Coronavirus is a stress test for future climate shocks. Bloomberg Green. https://www.bloomberg.com/news/articles/2020-03-25/coronavirus-is-a-stress-test-for-future-climate-shocks

Dhaka Tribune. (2021, February 10). Bangladesh calls for international cooperation to tackle climate change. DhakaTribune. https://archive.dhakatribune.com/bangladesh/2021/02/10/bangladesh-calls-for-international-cooperation-to-tackleclimate-change

EJF. (2021, May 2). Climate displacement in Bangladesh. Environmental Justice Foundation. https://ejfoundation.org/reports/ climate-displacement-in-bangladesh

Hammer, S., Hallegatte, S., \& Banaji, F. (2020, May 3). How countries' climate ambitions can support a sustainable recovery from COVID-19 (Coronavirus). The World Bank Group. https://blogs.worldbank.org/climatechange/how-countries-climateambitions-can-support-sustainable-recovery-covid-19-coronavirus

Hasan, K., \& Shaon, A. I. (2020, March 8). First 3 cases of coronavirus confirmed in Bangladesh. DhakaTribune. https://archive.dhakatribune.com/health/coronavirus/2020/03/08/iedcr-3-affected-with-coronavirus-in-bangladesh

Huq, S. (2020, August 14). Four lessons from COVID-19 pandemic for tackling climate change. The Daily Star. https://www.thedailystar.net/opinion/politics-climate-change/news/four-lessons-covid-19-pandemic-tackling-climatechange-1944561

Huq, S. (2021, March 17). Invest in knowledge generation and capacity-building to tackle climate change. The Daily Star. https://www.thedailystar.net/opinion/news/invest-knowledge-generation-and-capacity-building-tackle-climate-change2061701

Khan, A. E., Xun, W. W., Ahsan, H., \& Vineis, P. (2011). Climate change, sea-level rise, \& health impacts in Bangladesh. Environment: Science and Policy for Sustainable Development, 53(5). https://doi.org/10.1080/00139157.2011.604008

Klenert, D., Funke, F., Mattauch, L. \& O'Callaghan, B. (2020). Five lessons from COVID-19 for advancing climate change mitigation. Environmental and Resource Economics, 76(4), 751-778. https://doi.org/10.1007/s10640-020-00453-w

Mamun, S. (2020, March 23). Coronavirus: Bangladesh declares public holiday from March 26 to April 4. DhakaTribune. https://archive.dhakatribune.com/bangladesh/2020/03/23/govt-offices-to-remain-closed-till-april-4

Meuleman, L. (2020, May 3). It takes more than markets: First governance lessons from the COVID-19 pandemic. International Institute for Sustainable Development. https://sdg.iisd.org/commentary/guest-articles/it-takes-more-than-markets-firstgovernance-lessons-from-the-covid-19-pandemic/

Noman, M. (2021, April 9). Seven-day strict lockdown from 14 April. The Business Standard. https://www.tbsnews.net/coronaviruschronicle/covid-19-bangladesh/govt-private-offices-remain-closed-7-days-april-14-229216

Pathak, P. K., Singh, Y., Mahapatro, S. R., Tripathi, N., \& Jee, J. (2020). Assessing socioeconomic vulnerabilities related to COVID-19 risk in India: A state-level analysis. Disaster Medicine and Public Health Preparedness, 1-14. https://doi.org/10.1017/dmp.2020.348 
Perera, W. (2020, May 5). Bangladesh government downplays COVID-19 threat as job losses mount. International Committee of the Fourth International. https://www.wsws.org/en/articles/2020/03/16/bang-m16.html

Shammi, M., Bodrud-Doza, Md., Towfiqul Islam, A. R. Md., \& Rahman, Md.M. (2020). COVID-19 pandemic, socioeconomic crisis and human stress in resource-limited settings: A case from Bangladesh. Heliyon, 6(5), e04063. https://doi.org/10.1016/j.heliyon.2020.e04063

Swapan, A. R., \& Tuhin, A. C. (2021, April 21). Diarrhoea outbreak: 8 dead, thousands hospitalized across Barisal division. DhakaTribune. https://archive.dhakatribune.com/bangladesh/nation/2021/04/21/

Wang, C. J., Ng, C. Y., \& Brook, R. H. (2020). Response to COVID-19 in Taiwan: Big data analytics, new technology, and proactive testing. The Journal of the American Medical Association, 323(14), 1341-1342. https://doi.org/10.1001/jama.2020.3151

Worldometer. (2021, April 13). World/countries/Bangladesh. Worldometer. https://www.worldometers.info/coronavirus/country/ bangladesh/ 